\title{
PERTANGGUNGJAWABAN DAN UPAYA HUKUM PEMBAYARAN UTANG KLAIM ASURANSI TERHADAP PEMEGANG POLIS AKIBAT KEPAILITAN PERUSAHAAN ASURANSI
}

\author{
M. Alifadhil Syahran, Fakultas Hukum Universitas Udayana, \\ e-mail: syahranfadhil@gmail.com \\ Marwanto, Fakultas Hukum Universitas Udayana, \\ e-mail: marwanto.jim@gmail.com
}

doi: https://doi.org/10.24843/KS.2020.v08.i11.p13

\begin{abstract}
ABSTRAK
Pertanggungjawaban yang dilakukan oleh perusahaan asuransi yang dinyatakan pailit terhadap pemegang polis adalah dengan membayarkan utang klaim asuransi yang pengurusan terhadap pembayaran tersebut dilaksanakan oleh kurator sebagai pengurus dari harta kekayaan debitor dan upaya hukum yang dapat dilakukan oleh pemegang polis adalah memohonkan permohonan pailit yang diwakilkan oleh otoritas jasa keuangan ke pengadilan niaga. Metode penelitian yang dilakukan dari penulisan ini adalah hukum normatif dengan mengacu kepada berbagai bahan pustaka atau data sekunder serta melakukan pendekatan perundang-undangan dan pendekatan konseptual. Hasil studi terhadap penulisan ini menunjukkan bahwasanya perusahaan asuransi yang telah dinyatakan pailit oleh pengadilan niaga memiliki bentuk pertanggungjawaban untuk membayarkan utang klaim asuransi terhadap pemegang polis dan pemegang polis dapat menempuh upaya hukum untuk memohonkan pailitnya perusahaan asuransi.
\end{abstract}

Kata Kunci: Pertanggungjawaban, Upaya Hukum, Pemegang Polis, Utang Klaim Asuransi

\section{ABSTRACT}

The responsibility for the insurance company that is declared bankrupt to the policyholder is to pay the insurance claim debt, which the management of the payment is carried out by the curator as the manager of the debtor's assets and legal effort that can be taken by the policyholder is to apply for bankruptcy represented by the service authority finance to the commercial court. The research method used from this writing is normative law by referring to various library materials or secondary data as well as taking a staturoy approach and conceptual approach. The result of the study on this writing show that insurance companies that have been declared bankrupt by commercial court have a form of responsibility to pay insurance claims debts against policyholders and policyholder also can take a legal effort to petition the insurance company for bankruptcy.

Key Words: Accountability, Legal Effort, Policyholders, Insurance Claim Debt.

\section{Pendahuluan}

\subsection{Latar Belakang Masalah}

Di dalam perkembangan dunia bisnis yang sangat pesat, terdapat hal-hal yang sering dilakukan dan dipergunakan oleh subjek hukum untuk mengembangkan kegiatan bisnis yang akan dijalaninya. Hadirnya perusahaan asuransi ke dalam trend bisnis yang menarik dan menguntungkan bagi para subjek hukum, menjadikan perusahaan asuransi hadir sebagai salah satu badan hukum yang memiliki pengaruh besar bagi individu maupun kelompok di dalam kehidupan sehari-hari. beranjak dari ketertarikan masyarakat terhadap kegiatan bisnis yang dijalani oleh perusahaan asuransi maka kedepannya jenis usaha asuransi yang menghimpun dana dari 
masyarakat untuk kepentingan di masa depan atau yang akan datang menjadi sangat diminati dan diyakini dapat membantu kegiatan di dalam menjalani setiap aktivitasaktivitas bisnis. Perusahaan asuransi berkembang sangat pesat, luas dan cepat sehingga menjadikan kegiatan perasuransian banyak digunakan oleh masyarakat karena mendapatkan kepercayaan yang sangat besar di dalam menjalankan kegiatan sehari-hari. Usaha kegiatan perasuransian menawarkan jasa untuk memberikan ganti kerugian yang terjadi terhadap resiko para pemegang polis sesuai dengan perjanjian polis yang telah disepakati sebelumnya. ${ }^{1}$

Definisi asuransi terdapat dalam Kitab Undang-Undang Hukum Dagang (selanjutnya disebut KUHD) Pasal 246 yaitu "asuransi atau pertanggungan adalah suatu perjanjian, dengan mana seorang penanggung mengikatkan diri kepada seorang tertanggung, dengan menerima suatu premi, untuk memberikan penggantian kepadanya karena suatu kerguian, kerusakan atau kehilangan keuntungan yang diharapkan, yang mungkin akan dideritanya karena suatu peristiwa yang tak tertentu." Berdasarkan Undang-Undang Nomor 40 Tahun 2014 tentang Perasuransian (selanjutnya disebut UU Perasuransian) asuransi yaitu perjanjian para pihak, antara perusahaan asuransi dan pemegang polis yang menjadikan premi sebagai hak bagi pemegang polis jika nantinya terjadi suatu hal sesuai dengan perjanjian polis asuransi. Jika mengacu kepada UU Perasuransian, maka terjadinya suatu perjanjian dari para pihak antara perusahaan asuransi dan pemegang polis adalah dikarenakan adanya kata sepakat yang saling mengikat antara tertanggung dan penanggung yang akta itu disebut polis asuransi. ${ }^{2}$ Berdasarkan dengan Pasal 1320 Kitab Undang-Undang Hukum Perdata (selanjutnya disebut KUHPerdata) tentang sahnya perjanjian mengharuskan adanya konsensus bagi kedua pihak sehingga perjanjian tersebut dapat memiliki kata sepakat di dalamnya sehingga jika berkaitan dengan polis asuransi antara perusahaan asuransi dan pemegang polis harus mencapai kata sepakat terlebih dahulu.

Kebutuhan terhadap perlindungan yang diperlukan oleh masyarakat terhadap kontrak polis asuransi berasal dari kecemasan yang muncul dari dalam diri untuk memecahkan suatu ketidakpastian yang akan terjadi di masa depan. Tiap-tiap resiko yang akan timbul seperti kecelakaan, bencana alam, ketidakmampuan dan kesalahan sangat memerlukan adanya perlindungan hukum, di sinilah peran dari perusahaan asuransi yang dapat memberikan solusi akan kecemasan tersebut. ${ }^{3}$ Untuk mencegah terjadinya hal-hal demikian maka hadirlah suatu produk dari perusahaan asuransi yang menawarkan polis asuransi atau perjanjian asuransi. Polis asuransi diatur sedemikian rupa oleh perusahaan asuransi yang menjadi hal dasar bagi pihak-pihak untuk mematuhi dan menjalankannya, tetapi seringkali di dalam prakteknya yang tidak sesuai dengan harapan menimbulkan berbagai macam polemik ketimpangan antara pemegang polis dan perusahaan asuransi, dimana terkadang perusahaan asuransi mengabaikan hak-hak yang timbul dari pemegang polis, sehingga menimbulkan rasa kecewa dari pemegang polis itu sendiri. ${ }^{4}$

1 Sulistyawati, Ni Putu Eni, dan I. Ketut Sudantra. "Perlindungan Hukum Bagi Pihak Ketiga Dalam Perjanjian Asuransi Kendaraan Bermotor Rent a Car di Kota Denpasar (Studi Kasus Pada Pt. Asuransi Wahana Tata Dan Pt. Asuransi Astra Buana)." Kertha Semaya: Journal Ilmu Hukum, Universitas Udayana, Vol. 5 No 1, (2017): 2.

2 Putri, Vianda Karina Ika, Bambang Winarno, dan A. Rachmad Budiono. "Tinjauan Yuridis Terhadap Polis Elektronik Dalam Perjanjian Asuransi." Syariah: Jurnal Hukum dan Pemikiran, Vol. 17, No 1, (2017): 2.

${ }^{3}$ Ibid.

${ }^{4} \mathrm{Ibid}, 3$. 
Apabila perusahaan asuransi berada dalam masa yang kritis dan pada saat itu juga klaim-klaim asuransi yang diajukan dari pemegang polis tidak dilaksanakan karena ketidakmampuannya untuk membayar utang tersebut, maka demi hukum hal tersebut menimbulkan utang dan pertanggungjawaban yang dialami perusahaan asuransi, hal tersebut akan memunculkan piutang atau uang yang belum dibayarkan bagi pemegang polis, sehingga pemegang polis berhak atas uang tersebut dan meminta kepada perusahaan asuransi untuk membayarkan utang klaim asuransi sesuai dengan polis asuransi yang telah disepakati sebelumnya. ${ }^{5}$ Filosofi dari kepailitan adalah adanya utang, karena inilah point utama dari proses kepailitan itu sendiri. Jikalau utang ini tidak ada maka tidak mungkin terjadi kepailitan yang dasarnya untuk melikuidasi aset atau harta dari debitor yang kegunaannya sematamata hanya untuk membayar utang-utang yang ditimbulkan dari perusahaan asuransi itu sendiri kepada kreditor-kreditornya. ${ }^{6}$ Di dalam perjalanannya telah banyak perusahaan asuranasi yang mempunyai utang-utang yang belum dibayarkan kepada pemegang polis, sehingga hal demikian memberikan peluang bagi pemegang polis untuk mengajukan permohonan pailit kepada pengadilan niaga.

Berdasarkan hal yang telah diuraikan pada latar belakang diatas maka penulis akan melakukan tinjauan yuridis secara komperhensif untuk mengetahui bentuk dari pertanggungjawaban serta upaya hukum bagi pemegang polis melalui tulisan yang berjudul "PERTANGGUNGJAWABAN DAN UPAYA HUKUM PEMBAYARAN UTANG KLAIM TERHADAP PEMEGANG POLIS AKIBAT KEPAILITAN PERUSAHAAN ASURANSI". Sebelumnya, telah terdapat 3 penelitian serupa yang membahas mengenai kepailitan perusahaan asuransi PT. Asuransi Bumi Asih Jaya yang ditulis oleh Muhammad Ridho dengan judul "Peran Otoritas Jasa Keuangan Dalam Melindungi Pemegang Polis Asuransi Akibat Pailitnya Perusahaan Asuransi (Studi Putusan Mahkamah Agung Nomor 408 K/Pdt.Sus-Pailit/2015) yang lebih mengkhusus membahas peran Otoritas Jasa Keuangan dalam melindungi pemegang polis, kemudian penelitian yang ditulis oleh Aditya Aryo Nugroho dengan judul "Kedudukan Hukum Tertanggung Atas Kepailitan Perusahaan Asuransi PT. Asuransi Jiwa Bumi Asih Jaya Dengan Adanya Putusan Nomor 408 K/PDT-PAILIT/2015" yang lebih mengkhusus membahas klaim asuransi dapat dinyatakan sebagai utang dan penyelesaian klaim asuransi yang telah dibayar tertanggung, dan penelitian yang ditulis oleh Tari Puspita dengan judul "Perlindungan Hukum Terhadap Pemegang Polis Asuransi Jiwa Yang Dirugikan Akibat Dari Kepailitan Perusahaan Asuransi (Analisis Putusan Kasasi Mahkamah Agung Republik Indonesia Nomor. 408 K/Pdt.Sus-Pailit/2015 Tentang Kepailitan PT. Asuransi Jiwa Bumi Asih Jaya)" yang lebih mengkhusus membahas perlindungan hukum yang didapatkan pemegang polis terhadap kepailitan PT. Asuransi Jiwa Bumi Asih Jaya. Sedangkan, dalam penelitian ini penulis lebih menitikberatkan kepada pertanggungjawaban dan upaya hukum yang dapat dilakukan oleh pemegang polis dalam hal terjadinya kepailitan terhadap perusahaan asuransi.

\subsection{Rumusan Masalah}

Berdasarkan latar belakang diatas, yang dapat menjadi rumusan masalah dalam jurnal ini adalah sebagai berikut:

${ }^{5}$ Marcella, Cloudiya. "Kajian Yuridis Kedudukan Pemegang Polis Dalam Kepailitan Perusahaan Asuransi." Diponegoro Law Journal, Vol. 5, No. 4, (2016): 3.

6 Shubhan, M. Hadi. "Hukum Kepailitan: Prinsip, Norma, dan Praktik di Peradilan." Jakarta: Kencana, (2009), 34. 
1. Apakah perusahaan asuransi yang telah dinyatakan pailit berdasarkan putusan nomor: $408 \mathrm{~K} /$ Pdt.Sus-Pailit/2015 dapat dimintakan pertanggungjawaban untuk membayar utang berupa klaim asuransi kepada pemegang polis?

2. Upaya hukum apakah yang dapat ditempuh oleh pemegang polis untuk mendapatkan klaim asuransi kepada perusahaan asuransi yang telah dinyatakan pailit?

\subsection{Tujuan Penulisan}

Adapun tujuan dari penulisan ini adalah sebagai berikut:

1. Untuk mengidentifikasi pertanggungjawaban dari perusahaan asuransi dalam pembayaran utang berupa klaim asuransi kepada pemegang polis.

2. Untuk mengidentifikasi upaya hukum yang dapat ditempuh oleh pemegang polis untuk mendapatkan klaim asuransi kepada perusahaan asuransi yang telah dinyatakan pailit.

\section{Metode Penelitian}

Penulisan didalam jurnal ini menggunakan metode penelitian hukum normatif dengan mengacu kepada berbagai bahan pustaka atau data sekunder serta melakukan pendekatan perundang-undangan dan pendekatan konseptual. Didalam penulisan jurnal ini penulis menggunakan bahan hukum primer untuk dijadikan dasar hukum dalam penelitian ini antara lain: Kitab Undang-Undang Hukum Dagang, Kitab Undang-Undang Hukum Perdata, Undang-Undang Nomor 37 Tahun 2004 tentang Kepailitan dan Penundaan Kewajiban Pembayaran Utang, Undang-Undang Nomor 21 Tahun 2001 tentang Otoritas Jasa Keuangan, Undang-Undang Nomor 40 Tahun 2014 tentang Perasuransian, dan Undang-Undang Nomor 40 Tahun 2007 tentang Perseroan Terbatas. Kemudian bahan hukum sekunder digunakan untuk mendukung dalam penggunaan bahan hukum primer diantaranya: asas-asas hukum, dan bahan-bahan kepustakaan terkait hukum kepailitan. Serta penulis juga menggunakan Teknik analisis bahan hukum melalui analisis kualitatif dan komprehensif untuk memberikan penjelesan dan menyelesaikan permasalahan didalam penulisan jurnal ini.

\section{Hasil dan Pembahasan}

\subsection{Pertanggungjawaban Perusahaan Asuransi Kepada Pemegang Polis}

Tanggung jawab perusahaan asuransi telah dimulai sejak kesepakatan di dalam kontrak polis asuransi disepakati oleh pemegang polis dan perusahaan asuransi. Sehingga pada hari itu juga muncul bentuk pertanggungjawaban yang harus selalu ditaati baik dari perusahaan asuransi maupun dari pemegang polis. Oleh karena itu, muncullah rasa bertanggung jawab dalam melaksanakan perjanjian tersebut. Jika tanggung jawab tidak dilaksanakan dari salah satu pihak, maka hal ini menyebabkan masalah terhadap perbuatan melawan hukum yang dilakukan oleh perusahaan asuransi.

Berkaitan dengan hal diatas maka kepailitan hadir untuk menyelesaikan permasalahan tersebut. Pailit merupakan keadaan pada saat debitor yang sudah benarbenar tidak mampu lagi untuk memberikan pembayaran terhadap semua utangnya yang telah jatuh tempo dan dapat ditagih, sehingga secara hukum para kreditornya dapat mengajukan permohonan pailit ke pengadilan niaga. Terjadinya suatu keadaan perusahaan asuransi telah sulit untuk mengatur manajemen keuangan yang ada di perusahaan yang disebabkan dari berbagai faktor, sehingga merugikan perusahaan asuransi. Jika dilihat di dalam ketentuan Pasal 1267 KUHPerdata yang mensyaratkan 
kewajiban ganti rugi terhadap pihak yang tidak memenuhi perikatan dapat di mintakan pembatalan persetujuan atau pergantian biaya. Berdasarkan hal tersebut pemegang polis dapat menuntut hak nya untuk pembayaran klaim polis kepada perusahaan asuransi.7

Kepailitan merupakan suatu jalan yang tepat bagi debitor untuk keluar dari permasalahan utang yang dialami oleh debitor sejak lama sehingga proses dari pembayaran utang yang akan dilakukan debitor akan terselesaikan dengan cepat, keadaan diajukannya suatu permohonan pailit terhadap perusahaan asuransi adalah jika terdapat keadaan dimana debitor tidak mampu lagi untuk membayar sebagian atau seluruh utang-utangnya (insolvency) dan sengaja untuk tidak membayar utang tersebut kepada pemegang polisnya. Berdasarkan hal diatas maka sangat memungkinkan bagi pemegang polis untuk melakukan langkah mengajukan permohonan kepailitan ke pengadilan niaga. ${ }^{8}$

Setiap permasalahan yang dimiliki perusahaan asuransi terhadap pemegang polisnya haruslah dilandaskan dengan prinsip tanggung jawab untuk melakukan pembayaran utang tersebut. ${ }^{9}$ Tanggung jawab dalam Bahasa belanda yakni vereentwoodelijk bahwa segala bentuk perbuatan yang dilakukan haruslah memiliki rasa untuk bertanggung jawab terhadap perbuatan yang dilakukan tersebut. Berdasarkan Pasal 1365 KUHPerdata menjelaskan secara jelas jika setiap perbuatan yang telah melanggar hukum dan menyebabkan kerugian bagi orang lain, maka akan hal tersebut mewajibkan orang yang bersangkutan untuk mengganti kerugian yang disebabkannya, sedangkan berkaitan dengan hal diatas Pasal 1366 KUHPerdata merincikan bahwa bentuk dari tanggung jawab orang tersebut tidak saja hanya untuk kerugian yang disebabkan karena perbuatannya, tetapi juga karena kelalaian dan kurang hati-hatinya.

Berkaitan dengan masalah utang yang dialami oleh perusahaan asuransi, maka secara hukum perusahaan tersebut harus bertanggung jawab mutlak atas kerugian dari pemegang polis tanpa terlebih dahulu harus membuktikan ada atau tidaknya kesalahan pada perusahaan asuransi. Secara umum pemberlakuan prinsip tanggung jawab mutlak adalah untuk menunjukkan mengenai kerugian yang telah diderita pemegang polis. Dengan menggunakan prinsip tanggung jawab mutlak, ${ }^{10}$ maka permasalahan yang dialami oleh pemegang polis akan diketahui secara jelas. Perusahaan asuransi yang tidak mampu membayar utangnya kepada pemegang polis sudah dengan jelas telah melanggar prinsip itikad baik dan kontrak polis asuransi terhadap pemegang polisnya, dengan pemberlakuan prinsip tanggung jawab mutlak

7 Setiawati, Neneng Sri. "Perlindungan Hukum Terhadap Pemegang Polis Asuransi Dalam Menyelesaikan Sengketa Klaim Asuransi." Jurnal SPEKTRUM HUKUM, Vol. 15 No. 1, (2018): 8 .

8 Setiarso, Adi Nugroho. "Analisis Yuridis Terhadap Keadaan Insolvensi Dalam Kepailitan (Studi Normatif Pasal 2 ayat 1 Undang-undang No 37 Tahun 2004 Tentang Kepailitan dan Penundaan Kewajiban Pembayaran Utang)." Kumpulan Mahasiswa Fakultas Hukum 1, No. 3 (2013): 3.

9 Ackbar, Muhammad, dan AA Gede Agung Dharmakusuma. "Pertanggungjawaban Debitor Pailit Terhadap Utang Yang Belum Terlunasi Dalam Perkara Kepailitan." Kertha Semaya: Journal Ilmu Hukum, Vol. 06, No. 01, (2018): 3.

10 Nur, Yudha Hadian, dan Dwi Wahyuniarti Prabowo. "Penerapan Prinsip Tanggung Jawab Mutlak (Strict Liability) Dalam Rangka Perlindungan Konsumen." Buletin Ilmiah Litbang Perdagangan, Vol 5, No. 2, (2011): 6. 
perusahaan asuransi yang lalai akan kewajibannya akan mendapatkan hukuman yang berat terhadap perbuatan yang dilakukannya. ${ }^{11}$

Bahwa dikarenakan PT. Asuransi Bumi Asih Jaya tidak melaksanakan kewajibannya dengan tidak membayarkan klaim dari para pemegang polis sesuai perjanjian yang telah disepakati sebelumnya dengan total klaim manfaat asuransi yang harus dibayarkan "sebesar Rp 831.127.649 (delapan ratus tiga puluh satu juta seratus dua puluh tujuh ribu enam ratus empat puluh sembilan rupiah) dengan jumlah pemegang polis mencapai 34 (tiga puluh empat) orang dan laporan operasional triwulan II dari PT. Asuransi Bumi Asih Jaya saldo utang klaim asuransi per 30 Juni 2013 sebesar Rp. 110.748.000.000 (seratus sepuluh miliar tujuh ratus empat puluh delapan juta rupiah) dengan jumlah pemegang polis 13.209 (tiga belas ribu dua ratus sembilan) orang. Berdasarkan putusan nomor: $408 \mathrm{~K} / \mathrm{Pdt} . S u s-P a i l i t / 2015$ yang mengabulkan permohonan kasasi dari Otoritas Jasa Keuangan dan dimana pemegang polis diklasifikasikan sebagai kreditor yang memiliki utang yang harus dibayarkan. Sehingga PT. Asuransi Jiwa Bumi Asih Jaya wajib untuk membayarkan semua klaim yang telah diajukan pemegang polis. ${ }^{12}$

Beranjak dari putusan pailit terhadap PT. Asuransi Bumi Asih Jaya maka pengurusan dari harta debitor akan dilakukan oleh Kurator yang telah ditetapkan oleh Majelis Hakim dengan mengelola harta kekayaan debitor setelah adanya putusan pailit dan debitor tidak memiliki kewenangan untuk mengelola kembali aset dari perusahaan tersebut. Oleh karena itu kewenangan pengelolaan atau pengurusan harta pailit milik debitor terhadap kreditor jatuh ke tangan kurator.

\subsection{Upaya Hukum Pemegang Polis Terhadap Pailitnya Perusahaan Asuransi}

Upaya hukum didalam suatu permasalahan adalah untuk menyelesaikan suatu kasus hukum yang dialami oleh seseorang, upaya hukum di dalam hukum acara perdata adalah jalur litigasi maupun non-litigasi. Di dalam permasalahan ini pemegang polis dapat melakukan upaya hukum litigasi untuk menyelesaikan permasalahan pembayaran utang klaim asuransi yang dialami. Upaya hukum yang diberikan dari peraturan perundang-undangan khususnya Undang-Undang Kepailitan dan PKPU dan UU Perasuransian memberikan ruang kepada pemegang polis untuk mendapatkan kepastian hukum terhadap upaya hukum yang dilakukan. Setiap permasalahan hukum di Indonesia haruslah menggunakan prinsip kepastian hukum, dengan berlandaskan prinsip ini maka suatu hukum telah sesuai dalam penerapan dan penegakannya. Keberadaan terhadap asas kepastian hukum disini adalah bentuk perlindungan terhadap setiap individu maupun kelompok untuk mencari keadilan terhadap tindakan yang merugikan yang dialami seseorang. Kepastian hukum disini diartikan sebagai upaya hukum yang dapat ditempuh oleh pemegang polis untuk memberikan perlindungan bagi pemegang polis yang sangat dirugikan akibat kelalaian yang ditimbulkan perusahaan asuransi, kepastian hukum disini dihadirkan dalam bentuk perlindungan bagi mereka yang dirugikan untuk menciptakan keadilan yang setara bagi semua pihak. Kepailitan merupakan pranata

11 Sormin, Asike Eunike, Mardalena Hanifah, dan Ulfia Hasanah. "Perlindungan Hukum Bagi Pemegang Polis Atas Perusahaan Asuransi Yang Dipailitkan Menurut Undang-Undang Nomor 37 Tahun 2004 tentang Kepailitan dan Penundaan Kewajiban Pembayaran Utang Pada PT. Asuransi Jiwa Bumi Asih Jaya Cabang Pekanbaru." Jurnal Fakultas Hukum, Vol. III No. 2, (2016): 10.

12 Shubhan, M. Hadi, op cit, 34. 
hukum bagi pemegang polis untuk mendapatkan kepastian hukum terhadap perbuatan debitor dalam mendapatkan kembali pembayaran utang klaim asuransi dari perusahaan asuransi yang dinyatakan pailit. ${ }^{13}$

Klaim asuransi merupakan tuntutan dari pemegang polis kepada perusahaan asuransi untuk melakukan pembayaran sejumlah uang yang telah disepakati dari polis asuransi. Perlu diketahui bahwa pemegang polis adalah salah satu dari macam-macam kreditor, kreditor dan debitor memiliki hak dan kewajiban yang harus dijalankan. Disinilah biasanya timbul pertentangan antara para pihak baik kreditor ataupun debitornya, biasanya kreditor akan dilunaskan utang-utangnya secara pari passu atau pro rata. ${ }^{14}$

Mengacu kepada permasalahan utang-utang yang dialami perusahaan asuransi, maka pemegang polis yang telah dirugikan oleh perusahaan asuransi akan mengajukan suatu upaya hukum dengan mengumpulkan bukti-bukti yang berkaitan dengan utang tersebut untuk kemudian digunakan sebagai laporan awal kepada Otoritas Jasa Keuangan. Pada saat permohonan dari pemegang polis tersebut diajukan ke Otoritas Jasa Keuangan, dalam jangka waktu 30 hari Otoritas Jasa Keuangan akan memberikan kualifikasi mengenai permohonan pailit tersebut dengan menyatakan jika permohonan tersebut disetujui atau ditolak karena dokumen-dokumen permohonan belum lengkap. Perlu dipahami jika kreditor atau pemegang polis tidak berhak untuk mengajukan permohonan kepailitan sendiri kepada pengadilan niaga, apabila Otoritas Jasa Keuangan merasa demi kepentingan konsumen perlu dilakukan pengajuan permohonan kepailitan dengan ada atau tidaknya permohonan yang diajukan oleh kreditor Otoritas Jasa Keuangan dapat langsung mengajukan permohonan pailit ke pengadilan niaga. Dapat dilihat disini bahwa pemegang polis bukanlah kreditor yang dalam posisi yang menguntungkan. Kemudian berdasarkan putusan nomor: 408 K/Pdt.Sus-Pailit/2015 diketahui bahwa pemegang polis adalah kreditor yang dijamin oleh Undang-Undang. Berdasarkan pada Pasal 52 UU Perasuransian menjelaskan bahwasanya jika suatu perusahaan asuransi dinyatakan pailit maka hak dari para pemegang polis didahulukan karena memiliki hak yang lebih tinggi daripada para pihak yang lain. ${ }^{15}$

Sesuai dengan ketentuan Pasal 25 Undang-Undang Otoritas Jasa Keuangan jika terjadi suatu sengketa atau permasalahan yang melibatkan setiap lembaga keuangan bank dan non-bank ${ }^{16}$, maka Otoritas Jasa Keuangan diwakili oleh Dewan Komisioner di dalam maupun diluar pengadilan. Dengan menggunakan asas kepastian hukum maka proses penyelesaian perkara kepailitan dilakukan secara cepat dengan menggunakan prinsip pembuktian sederhana, sehingga pemegang polis akan diuntungkan dalam menyelesaikan masalah pembayaran utang yang tidak kunjung dibayarkan perusahaan asuransi kepada nasabahnya.

Upaya hukum yang dilakukan pemegang polis untuk mendapatkan kepastian hukum diartikan sebagai bentuk dari perjuangan yang akan didapatkan oleh pemegang polis di dalam penyelesaian masalah kepailitan. Bentuk dari kepastian

${ }^{13}$ Makmur, Syafrudin. "Kepastian Hukum Kepailitan Bagi Kreditur dan Debitur Pada Pengadilan Niaga Indonesia." Mizan: Journal of Islamic Law, Vol. 4 No. 2, (2018): 10.

${ }^{14}$ Jono. "Hukum Kepailitan." (Jakarta, Sinar Grafika, 2015), 3.

15 Pawitri, Rosiani Niti. "Kedudukan Dan Perlindungan Hukum Pemegang Polis Pada Perusahaan Asuransi Yang Pailit Berdasarkan Undang-Undang Nomor 40 Tahun 2014 Tentang Perasuransian." Wacana Hukum, Vol. 23, No. 1, (2018): 47.

16 Hesti, Yulia. "Analisis Yuridis Tujuan Dan Kewenangan Otoritas Jasa Keuangan (OJK) Dalam Lembaga Perbankan di Indonesia." PRANATA HUKUM, Vol. 13 No. 2, (2018): 3. 
hukum harus diwujudkan oleh hakim untuk memberikan perlindungan hukum yang tepat terhadap tindakan yang dilakukan oleh perusahaan asuransi dengan tidak membayarkan utangnya kepada pemegang polis.

Undang-Undang Kepailitan dan PKPU memberikan ruang bagi debitor, kreditor, dan para pihak lainnya untuk mengajukan permohonan pailit, perdamaian, penundaan kewajiban pembayaran utang sebagai bentuk kepastian hukum, keadilan dan kemanfaatan yang harus dirasakan oleh seluruh pihak yang terkait untuk menjamin jalannya hukum secara adil dan berkesesuaian. Maka permasalahan di dalam kepailitan akan lebih jelas setelah menggunakan prinsip kepastian hukum dalam penyelesaian perkara kepailitan. Peran dari hakim untuk memberikan kepastian hukum terhadap perkara-perkara kepailitan yang ditanganinya akan memberikan kepercayaan kepada pemegang polis dalam masalah yang mereka alami. Adanya suatu putusan pailit sangat melihat sekali aspek yang mempertimbangkan penyelesaian terhadap kepastian hukum, keadilan dan kemanfaatan berdasarkan masalah kepailitan tersebut.

\section{Kesimpulan}

Berdasarkan hasil penelitian yang penulis lakukan dapat disimpulkan bahwa dalam hal terjadinya kepailitan terhadap perusahaan asuransi, maka perusahaan asuransi memiliki tanggungjawab penuh terhadap pembayaran utang klaim asuransi kepada pemegang polis yang pengurusan harta pailit dilakukan oleh kurator yang telah ditetapkan oleh majelis hakim berdasarkan putusan nomor: $408 \mathrm{~K} /$ Pdt.SusPailit/2015. Kemudian upaya hukum yang dapat dilakukan oleh pemegang polis untuk memperoleh pembayaran dari klaim asuransi yang diajukannya adalah dengan membuat laporan kepada Otoritas Jasa Keuangan untuk memohonkan permohonan pailit kepada perusahaan asuransi, sehingga Otoritas Jasa Keuangan berdasarkan kepentingan konsumen maka Otoritas Jasa Keuangan akan mengajukan permohonan pernyataan pailit ke Pengadilan Niaga untuk memohon adanya putusan pailit terhadap perusahaan asuransi.

\section{Daftar Pustaka}

\section{Buku}

Jono. Hukum Kepailitan, Jakarta: Sinar Grafika, (2015).

Shubhan, M. Hadi. Hukum Kepailitan: Prinsip, Norma, dan Praktik di Peradilan Jakarta: Kencana, (2009).

Sjahdeini, Sutan Remy, Sejarah, Asas, Dan Teori Hukum Kepailitan Memahami UndangUndang No. 37 Tahun 2004 tentang Kepailitan dan Penundaan Kewajiban Pembayaran Edisi Kedua, Jakarta: Prenadamedia Group, (2016).

\section{Jurnal}

Ackbar, Muhammad, dan AA Gede Agung Dharmakusuma. “Pertanggungjawaban Debitor Pailit Terhadap Utang Yang Belum Terlunasi Dalam Perkara Kepailitan." Kertha Semaya: Journal Ilmu Hukum, Vol. 06, No. 01, (2018): 3.

Hesti, Yulia. "Analisis Yuridis Tujuan Dan Kewenangan Otoritas Jasa Keuangan (OJK) Dalam Lembaga Perbankan di Indonesia." PRANATA HUKUM, Vol. 13 No. 2, (2018): 3.

Makmur, Syafrudin. "Kepastian Hukum Kepailitan Bagi Kreditur dan Debitur Pada Pengadilan Niaga Indonesia." Mizan: Journal of Islamic Law, Vol. 4 No. 2, (2018): 10. 
Marcella, Cloudiya. "Kajian Yuridis Kedudukan Pemegang Polis Dalam Kepailitan Perusahaan Asuransi." Diponegoro Law Journal, Vol. 5, No. 4, (2016): 3.

Nur, Yudha Hadian, dan Dwi Wahyuniarti Prabowo. "Penerapan Prinsip Tanggung Jawab Mutlak (Strict Liability) Dalam Rangka Perlindungan Konsumen." Buletin Ilmiah Litbang Perdagangan, Vol 5, No. 2, (2011): 6.

Pawitri, Rosiani Niti. "Kedudukan Dan Perlindungan Hukum Pemegang Polis Pada Perusahaan Asuransi Yang Pailit Berdasarkan Undang-Undang Nomor 40 Tahun 2014 Tentang Perasuransian." Wacana Hukum, Vol. 23, No. 1, (2018): 47.

Putri, Vianda Karina Ika, Bambang Winarno, dan A. Rachmad Budiono. "Tinjauan Yuridis Terhadap Polis Elektronik Dalam Perjanjian Asuransi." Syariah: Jurnal Hukum dan Pemikiran, Vol. 17, No 1, (2017): 2.

Setiarso, Adi Nugroho. "Analisis Yuridis Terhadap Keadaan Insolvensi Dalam Kepailitan (Studi Normatif Pasal 2 ayat 1 Undang-undang No 37 Tahun 2004 Tentang Kepailitan dan Penundaan Kewajiban Pembayaran Utang)." Kumpulan Mahasiswa Fakultas Hukum 1, No. 3 (2013): 3.

Setiawati, Neneng Sri. "Perlindungan Hukum Terhadap Pemegang Polis Asuransi Dalam Menyelesaikan Sengketa Klaim Asuransi." Jurnal SPEKTRUM HUKUM, Vol. 15 No. 1, (2018): 8.

Sormin, Asike Eunike, Mardalena Hanifah, dan Ulfia Hasanah. "Perlindungan Hukum Bagi Pemegang Polis Atas Perusahaan Asuransi Yang Dipailitkan Menurut Undang-Undang Nomor 37 Tahun 2004 tentang Kepailitan dan Penundaan Kewajiban Pembayaran Utang Pada PT. Asuransi Jiwa Bumi Asih Jaya Cabang Pekanbaru." Jurnal Fakultas Hukum, Vol. III No. 2, (2016): 10.

Sulistyawati, Ni Putu Eni, dan I. Ketut Sudantra. "Perlindungan Hukum Bagi Pihak Ketiga Dalam Perjanjian Asuransi Kendaraan Bermotor Rent a Car di Kota Denpasar (Studi Kasus Pada Pt. Asuransi Wahana Tata Dan Pt. Asuransi Astra Buana)." Kertha Semaya: Journal Ilmu Hukum, Universitas Udayana, Vol. 5 No 1, (2017): 2.

\section{$\underline{\text { Skripsi }}$}

S, Rayhana dan Abdul Salam. "Pertanggungjawaban atas Perbuatan Melawan Hukum Terhadap Tubuh dan Jiwa Manusia dalam Kecelakaan Lalu Lintas Studi Kasus Putusan Nomor: 04/Pdt.G/2013/PN/Psr)." Fakultas Hukum Universitas Indonesia, (2014).

\section{Peraturan Perundang-Undangan}

Kitab Undang-Undang Hukum Dagang, terjemahan Wetboek van Koophandel, Penyunting: Tim Redaksi Pustaka Yustitia, 2013, Penerbit Pustaka Yustitia, Yogyakarta.

Kitab Undang-Undang Hukum Perdata, terjemahan Burgerlijk Wetboek, Diterjemahkan oleh Prof. R. Subekti, S.H., dan R. Tjitrosudibio, 2012, PT Balai Pustaka (Persero), Jakarta.

Indonesia, Undang-Undang Nomor 37 Tahun 2004 tentang Kepailitan dan Penundaan Kewajiban Pembayaran Utang, Lembaran Negara Republik Indonesia Tahun 2004 Nomor 131, Tambahan Lembaran Negara Republik Indonesia Nomor 4443.

Indonesia, Undang-Undang Nomor 21 Tahun 2001 tentang Otoritas Jasa Keuangan, Lembaran Negara Republik Indonesia Tahun 2011 Nomor 111, Tambahan Lembaran Negara Republik Indonesia Nomor 5253. 
Indonesia, Undang-Undang Nomor 40 Tahun 2014 tentang Perasuransian, Lembaran Negara Republik Indonesia Tahun 2014 Nomor 337, Tambahan Lembaran Negara Republik Indonesia Nomor 5618.

Indonesia, Undang-Undang Nomor 40 Tahun 2007 tentang Perseroan Terbatas, Lembaran Negara Republik Indonesia Tahun 2007 Nomor 106, Tambahan Lembaran Negara Republik Indonesia Nomor 4756. 